This PDF is a selection from a published volume from the National Bureau of Economic Research

Volume Title: Measuring and Managing Federal Financial Risk

Volume Author/Editor: Deborah Lucas, editor

Volume Publisher: University of Chicago Press

Volume ISBN: 0-226-49658-9

Volume URL: http://www.nber.org/books/luca07-1

Conference Date: February 8-9, 2007

Publication Date: February 2010

Chapter Title: The Cost of Risk to the Government and Its Implications for Federal Budgeting

Chapter Author: Deborah Lucas, Marvin Phaup

Chapter URL: http://www.nber.org/chapters/c3039

Chapter pages in book: (29 - 54) 


\title{
The Cost of Risk to the Government and Its Implications for Federal Budgeting
}

\author{
Deborah Lucas and Marvin Phaup
}

\subsection{Introduction}

The idea of "state prices" - that the value today of a dollar in future purchasing power depends on the future state of nature-dates back to the classic work of Arrow and Debreu (1954) and Debreu (1959) and is the basis for most neoclassical theories of asset valuation used today. It offers an explanation for why some securities, such as common stocks and risky loans, earn an expected return in excess of the risk-free rate: these securities tend to have high payoffs when the economy is strong and low payoffs when the economy is weak. Since dollars received in good times are worth less in utility terms than in bad times (a result of decreasing marginal utility of wealth), the price of a risky security is less than its expected payoff discounted at the risk-free rate. Equivalently, its expected return is higher than the risk-free rate; there is a market risk premium.

While it is widely accepted that investors require a market risk premium, it is less established that market risk should be treated as a cost to the Federal Government. In practice, the price of risk is almost entirely absent from federal budgeting. This omission makes federal credit and some insurance programs appear to cost less than their market value, thereby favoring such assistance over alternatives that are accounted for at market prices. It also gives federal investments in risky securities financed

Deborah Lucas is the former Donald C. Clark HSBC Professor of Consumer Finance at the Kellogg School of Management, Northwestern University, and is currently a research associate of the National Bureau of Economic Research. Marvin Phaup is professorial lecturer at the Trachtenberg School of Public Policy and Public Administration at George Washington University.

We are grateful to Andy Abel, Bob Dennis, Peter Diamond, Douglas Hamilton, Henning Bohn, and David Wilcox for helpful comments. 
with Treasury debt the appearance of generating free money for the government.

In this chapter, we revisit the question of the cost of risk to the Federal Government and its implications, both conceptual and practical, for federal budgeting. We begin in section 3.2 with a brief review of the academic literature that speaks directly to the cost. We then review the economic case for treating market risk as a legitimate cost and consider how this conclusion is affected by considerations such as the government's ability to increase risk pooling, to transfer resources across generations, and in general, to reduce credit market imperfections.

In section 3.3, after briefly describing the current budget treatment of credit, insurance, and investments in private securities, we present the "budgetary case" for including the cost of market risk in budget estimates. This requires an understanding of what budget estimates are used for and also of their limitations. In the debate over whether the cost of risk should be incorporated into budget estimates, an important but often overlooked observation is that the budget records only costs, not benefits. The question of whether it is socially optimal for the government to make a particular investment is distinct from the question of whether including the market cost of risk in budget estimates improves their usefulness to policymakers. Certainly, budget cost is an input into cost-benefit analyses of policies, but assessing benefits requires nonbudget information as well. To the extent that budget estimates have an allocative effect, it is because of aggregate spending limits, and because they are used to make comparisons between different types of expenditures that satisfy a given policy objective. To make such constraints and comparisons meaningful, budget accounting aims to price alternative expenditures in consistent units of cost. Since the government generally procures other goods and services at market prices, considerations of consistency and transparency favor using market values in budgeting for financial obligations as well. Alternatives for measuring and accounting for market risk in government transactions - and some of the practical difficulties involved - are also discussed.

Even if, in principle, market risk should be included in budget estimates, whether it is worthwhile to modify budgeting practice depends on whether the potential improvements are material. A number of academic studiesincluding several in this volume and a series of academic papers and studies by the Congressional Budget Office (CBO) - provide some evidence on the magnitudes involved. Those findings, reviewed in section 3.4, show that the distortions from neglecting the price of risk in some cases have been considerable and suggest that investing in the capacity to provide this information to lawmakers through the budget process is likely to be worthwhile. 


\subsection{Cost of Risk to the Government}

\subsubsection{The Early Debate}

The question of the cost of risk to the government received considerable attention in the mid- to late 1960s and early 1970s, but much less has been written on the topic since then. ${ }^{1}$ Academic interest during that period arose naturally from recent advances in general equilibrium theory-particularly the contributions of Arrow and Debreu (1954) and Debreu (1959). Those developments allowed more general welfare analyses of policy, underscored both the benefits of risk sharing and the aggregate limit on risk sharing, and clarified the role of market prices in aggregating the risk preferences of society.

In this vein, Diamond (1967) analyzed an economy with technology risk and a stock market. His conclusions regarding government investment can be paraphrased by saying that if markets are sufficiently complete for stock prices to reflect the social cost of risk, then those prices are also relevant to the government in evaluating its investment policy. In other words, the private cost of risk is a reasonable proxy for the social cost of risk and the right metric for evaluating government investment decisions. Hirshleifer $(1964,1966)$ reached similar conclusions and argued forcefully for the use of market prices.

A distinctly different view of the cost of risk to the government was put forth by other leading economists of the time. In Jorgenson et al. (1964), Samuelson and Vickrey argue that because of the large and diversified portfolio held by the government, the marginal return from public investment overall is virtually risk free and hence should be evaluated at the risk-free rate rather than the higher market rate demanded by less diversified individuals. In a very influential paper, Arrow and Lind (1970) formalize this argument. Specifically, they study a model with complete contingent claims (i.e., complete insurance markets) and no aggregate uncertainty. They conclude that in this setting, the social and private discount rate is equated at the risk-free rate. They further show that even when markets are incomplete, the cost of risk bearing to taxpayers goes to zero as the number of taxpayers becomes large and the share of risk borne by each diminishes.

Arrow and Lind acknowledge that these conclusions depend on the assumption that government investment entails no aggregate risk: "The results . . . depend on returns from a given public investment being independent of other components of national income" (1970, p. 373). They defend this assumption as plausible, asserting that correlated risk is likely to be

1. A notable exception is Bazelon and Smetters (1999), which also surveys some of the earlier literature and addresses many of the same issues as this chapter. 
insignificant for many government investments. This is also noted by Sandmo (1972, p. 287), who writes that the Hirshleifer view can be reconciled with Arrow and Lind's conclusions only by recognizing that

the two sets of arguments are based on entirely different assumptions concerning the relationship between private and public investment with respect to risk. Arrow and Lind assume that the returns on private and public investment are uncorrelated; indeed this assumption is crucial for their main result. The Hirshleifer view, however, is clearly based on the assumption that for each type of public investment it is possible to find a private industry such that the returns are highly correlated.

Sandmo goes on to suggest that for the modern economies of Europe and the United States, Hirshleifer's view is likely the more plausible one. Interestingly, he observes that the contributions of Sharpe (1964), Lintner (1965), and Modigliani and Miller (1958) - a body of work that provides the underpinning of modern financial economics - are highly relevant to this debate but rarely cited in the context of public investment.

A lively discussion of the closely related question of whether there is a well-defined social (risk-free) discount rate and whether it can be gleaned from market prices was also occurring at that time (see Sandmo and Dreze [1971] and references therein). The rate of time preference reflected in capital market prices - that is, Treasury rates - can lead to suboptimal government investment decisions when markets are incomplete. Analyses of these issues led to the broad conclusion that in the presence of distorting taxes and various other sources of market incompleteness, there is not a unique rate of time preference appropriate for evaluating all pubic investments. As in the debate about market risk, a critical question that was left unresolved is whether it is possible to determine a better general rule than relying on market prices for choosing a discount rate.

\subsubsection{The Economic Case}

In this section, we briefly revisit the arguments for and against using market prices to evaluate risky government investment opportunities and review some more recent evidence from the finance literature that bears on the question of whether, as Arrow and Lind posited, diversifiable risk is priced.

To explain the expected returns on risky assets, financial economists often abstract from the general notion of state prices and describe risk as falling into two broad categories: nondiversifiable or market risk, and diversifiable or idiosyncratic risk. Market risk arises from fluctuations in aggregate output, which logically is inclusive of the effects of government actions on the aggregate economy, including stabilization policy. Idiosyncratic risks, on the other hand, can in principle be avoided through insurance and other contractual risk-sharing arrangements and by portfolio diversification. When 
markets are complete, individual optimization eliminates idiosyncratic risk, and in equilibrium, only market risk is priced.

In terms of this decomposition of risk and return, evidence that idiosyncratic risk is not priced in financial markets supports Hirshleifer's position that markets are sufficiently complete for the government to rely on market prices. Conversely, evidence that idiosyncratic risk is priced supports Arrow and Lind's argument. Specifically, Arrow and Lind conjecture that the reason for the high rates of return on risky securities relative to the risk-free rate - the market risk premium - is mainly compensation for these diversifiable risks rather than for aggregate or market risk. If government investment more effectively diversifies risk than does the private sector, using a market discount rate that includes compensation for diversifiable risk would result in systematic undervaluation of government investments.

Since the 1970s, numerous empirical studies have examined whether diversifiable risk is priced in financial markets. Most cross-sectional evidence on asset returns suggests that this risk is not priced. In particular, tests of the Sharpe and Lintner Capital Asset Pricing Model (CAPM), which decomposes asset returns into market and idiosyncratic components, show that idiosyncratic risk has little or no explanatory power for the cross-section of stock returns. The CAPM, which equates market risk with the volatility of Standard and Poor's (S\&P) 500 returns, has been criticized for its low explanatory power. However, tests of better performing multifactor alternatives to the $\mathrm{CAPM}^{2}$ also provide little support for the idea that differences in idiosyncratic risk explain the cross-section of returns (e.g., Fama and French 1992). These empirical findings are consistent with the observation that even small investors can diversify financial risk quite inexpensively - for instance, through mutual funds - and that most large investors hold fairly diversified positions. This evidence weighs against the argument of Arrow and Lind that market prices overstate the cost of risk to the government because investors put excessive weight on diversifiable risk.

Some observers have also interpreted the equity premium puzzle - the inability of parameterized versions of standard neoclassical general equilibrium models to account for the historically high average spreads between risky securities and short-term Treasury rates - as evidence of capital market imperfections. Attempts to explain the equity premium puzzle by appealing to individual risk exposure, however, have been largely unsuccessful (e.g., Heaton and Lucas 1996). In fact, the robust predictions of economic theory put very few quantitative restrictions on price levels or returns, suggesting that the observed equity premium is difficult to interpret as evidence for or

2. Testing for whether only aggregate risk is priced is complicated by the difficulty of finding an adequate empirical proxy. As famously noted by Roll (1977), the CAPM may appear to be rejected in tests, not because it is wrong, but because the proxies for the market return are not close enough to the true market portfolio. 
against the efficiency of financial markets in sharing risk. Hence, we view this literature as silent on the question of whether market prices deviate from social values.

Some (mostly nonacademic) observers have further suggested that market risk is not costly to the government, because the government can borrow at a risk-free Treasury rate. The problem with this reasoning is that the cost of debt financing is only one component of the government's cost of capital. When the government finances risky investments by selling safe Treasury securities, investment risk is shifted onto current and future taxpayers and other federal stake holders, who effectively become equity holders in a leveraged investment.

Imagine, for instance, that the government finances an investment in common stock through the sale of Treasury securities. This is an exchange of financial assets between the public and private sector that as a first approximation should have no effect on aggregate real investment or output. To be concrete, assume that the government borrows $\$ 100$ to buy $\$ 100$ in stock and will liquidate the entire position in one year. The Treasury securities promise 5 percent risk free, whereas the stock will return-2 percent in a recession and 20 percent in a boom. Assuming an equal probability of a boom or a bust, the expected return on the stock is 9 percent, a 4 percent premium over the Treasury rate. At the end of the year, taxpayers are liable for repayment of the Treasury debt, regardless of whether the stock gains or loses value. In a recession, the government will be short \$7-money that must be obtained from the public through expenditure cuts, higher taxes, or increased debt liabilities. In a boom, it will be ahead by $\$ 15$, which again will be passed through to the public through changes in expenditures, taxes, or government debt. This shows that the stock is not really entirely financed by the Treasury debt. The public serves as the residual claimant of the return on the stock minus the Treasury rate; it is as if the public is a highly leveraged equity holder in the stock investment.

A taxpayer accepting the same risk in a private financial transaction would expect compensation equal to the levered market risk premium to participate. In fact, the same transaction is readily available to the public without government intervention. An individual can sell $\$ 100$ of Treasury securities and use the proceeds to invest $\$ 100$ in the common stock. The 4 percent increase in expected return is compensation for taking on the higher risk of the new portfolio, not an arbitrage gain.

The argument that the government cannot create value by exchanging safe for risky claims is an application to public finance of the well-known Modigliani-Miller theorem (Modigliani and Miller 1958). They show that in the absence of market imperfections, the cost of risk associated with an asset depends only on its own characteristics, not on the combination of financial securities used to finance it. In our example, the value of the stock purchased by the government is independent of the combina- 
tion of Treasury securities and contingent public obligations used to fund the purchase.

\subsubsection{Implications of Incomplete Markets}

Notwithstanding the preceding arguments for the relevance of market prices, market incompleteness can complicate the evaluation of social costs and benefits for risky government investments. ${ }^{3}$ In this section, we discuss several ways in which incomplete markets complicate valuation, but we emphasize the strong case for using market prices to measure costs, even in the presence of incomplete markets.

A classic example of market incompleteness arises in credit markets, where informational asymmetries combined with weak enforcement mechanisms can cause markets to break down. For instance, Stiglitz and Weiss (1981) consider a credit market with borrowers of mixed quality, where lenders cannot distinguish between borrower types. If lenders attempt to increase interest rates to make up for expected losses on bad credits, good borrowers leave the market, driving up the expected loss rate. In the extreme, no interest rate clears the market at a nonnegative profit to lenders. Private credit is rationed at a suboptimally low level relative to a "first-best" allocation.

When credit rationing occurs, it may be welfare improving for the government to intervene by making credit available. ${ }^{4}$ The federal student loan program, which provides credit for students who have little or no credit history and might not be able to obtain loans on their own, is an example of a government intervention thought to reduce such credit rationing. Of course, such interventions may not always improve welfare: credit subsidies will induce some people to borrow more than is socially desirable and can impose considerable costs on taxpayers. Since the marginal utilities of constrained borrowers are unobservable and likely to vary across individuals, it seems that evaluating the benefits from government credit programs will always include a subjective element.

Market incompleteness also complicates the evaluation of the cost of federal credit assistance. When private credit markets fail or when government credit crowds out private credit provision, an appropriate market price may not be readily identifiable. In such cases, using the standard methods in financial valuation discussed next, the cost-in terms of what markets (and presumably taxpayers) would demand for receiving the same statecontingent payoffs from borrowers - can be found by projecting those payoffs on securities that are trading in financial markets. This projection approach identifies the amount of market risk embedded in the transaction

3. Bohn (2004), for instance, examines the welfare effects of alternative fiscal policies when market incompleteness is generated by imperfect risk sharing across generations.

4. Gale (1991) observes that when government credit simply substitutes for credit that would have otherwise been privately extended and hence has little effect on real resource allocations, government provision has little effect on social welfare. 
and incorporates the price of market risk into the estimated cost to the government. For instance, one can infer the value of government student loans from market prices for unsecured consumer credit, and government credit guarantees to small businesses can be valued using information on similar, nonguaranteed bank loans to small firms. These examples illustrate that the absence of a market price does not preclude the existence of a similar private credit arrangement that can be used to infer market value. Further, the absence of an analogous private contract does not imply that a government program will be exceptionally expensive or risky; rather, it reflects the absence of a profitable private lending opportunity.

Future generations are not directly represented in current market transactions, and some economists believe that this source of incompleteness causes too little weight to be placed on the welfare of future generations when future costs and benefits are discounted at market rates. That is, the social cost of long-term federal liabilities and the social value of longterm public investments are both understated using market discount rates. This point of view, for example, was forcefully presented in Stern (2007). Others argue the opposite: because of investments made today and the fruits of technological progress, future generations will likely be better off, and hence it is optimal to incur liabilities that they will be at least partially responsible for.

How the competing interests of current and future generations should be weighed in public policy decisions is an important and difficult problem but one that may be largely separable from the question of whether the market price of risk should be incorporated into federal budget estimates. Kaplow (2006) develops a framework that formalizes the idea that the question of efficiency and of how much weight should be placed on different generations can be separated. In his analysis, increasing efficiency is to the benefit of all generations, and efficiency is properly assessed using market prices. To the extent that the purpose of the federal budget is to assist the government in making efficient trade-offs at a point in time, the implication of his analysis is that market prices are appropriate for federal budgeting, even when generational welfare is assessed at a below- or abovemarket rate.

It is important to note that if generational equity or other externalities cause one to seriously question the appropriateness of market prices for guiding government allocation decisions, these objections apply equally to the leading alternative for discounting government obligations: Treasury yields. Like the yields on risky securities, Treasury yields are determined by supply and demand in financial markets and hence fail to capture any nonmarket notion of the correct social discount rate.

In general, market incompleteness can drive a wedge between market prices and social costs and benefits. This is true for noncredit as well as credit programs and in itself does not justify selectively deviating from market 
prices in the case of budgeting for credit. Whether it is possible to improve upon market prices clearly will depend on the source and consequences of the market imperfection under consideration. We return to the issue of whether introducing risk adjustment in federal budgeting is likely to improve the allocative efficiency of the budget process in a second-best world in section 3.3.2.

\subsection{The Cost of Risk and the Federal Budget}

To evaluate the pros and cons of including the cost of risk in federal budget estimates, it is first necessary to understand the basic principles that govern budgetary accounting, and specifically the rules related to credit, insurance, and investments in private securities. ${ }^{5}$ It is also important to consider how Congress uses these estimates in making resource allocation decisions.

\subsubsection{Federal Budget Accounting}

The federal budget primarily relies on cash accounting to depict the cost of federal activities. This basis of accounting records federal costs in terms of net cash outlays in the year in which it occurs rather than when it accrues. The budget also includes projected outlays over a period of up to ten years. The out-year projections of cost receive less attention, however, because they do not affect the current budget deficit or surplus.

For certain long-lived contractual obligations such as capital leases, interest on Treasury securities, and federal credit assistance, the budget has moved gradually away from pure cash accounting in favor of up-front or capitalized accrual accounting. That treatment recognizes all projected payments associated with the obligation, even if some cash flows will occur outside the budget period. It also introduces discounting into budget calculations, which raises the question of whether and how risk should be accounted for.

The fact that the budget is primarily on a cash rather than accrual basis can distort resource allocation decisions-for instance, by making rental appear less costly than capital investment, even when in present value terms, the capital investment is cheaper and the facility will be used indefinitely. Accruals, however, require more assumptions about uncertain future cash flows, making them easier to manipulate. Assessing the pros and cons of cash versus accrual budgeting is beyond the scope of this analysis; we take the cash treatment of most expenditures as given. The main conclusions about risk adjustment, however, would appear to become even more important were accruals more widely used in the budget. 


\section{Loans and Loan Guarantees}

Before 1990, the budget cost for federal credit activity was similar to that for most other programs - the net cash outflows for the program in the fiscal year. The mix of cash flows included in the budget account made net outlays an inaccurate measure of cost. For existing programs, an increase in net outlays could result from increases in new lending, higher defaults on outstanding guarantees, legislated increases in debt forgiveness, or other factors. For new direct loan programs, the cost reported was not comprehensive and hence was also hard to evaluate. Cost included net outlays in the budget period but no offset for expected repayments outside the budget window and no adjustment for time value. New guarantee programs were scored with few, if any, cash outflows in the year the program began, because outlays for defaults usually occur a year or more after the loan is disbursed. In fact, new guarantees often had a negative cost because of the inflow of guarantee fees early on. This accounting favored new guarantee programs over almost all alternatives intended to achieve the same policy objectives, including new direct loan programs.

The Federal Credit Reform Act of 1990 (FCRA) effectively put credit on an accrual basis, with cost measured as the discounted value (at the maturity-matched Treasury rate) of current- and future-period cash flows from budget-period transactions. Its stated objectives were to: measure the cost of federal credit programs more accurately, place the cost of credit programs on a budgetary basis equivalent to other federal spending, encourage the delivery of benefits in the form most appropriate to the needs of beneficiaries, and improve the allocation of resources among credit programs and between credit and other spending programs.

Although the FCRA was partially successful in meeting its objectives, it fell short of measuring cost in terms completely equivalent to cash spending. The largest discrepancy arises from the mandated use of interest rates on maturity-matched US Treasury securities for discounting rather than a market-based cost of capital that includes the cost of market risk. ${ }^{6}$ The understatement of cost is most evident in those programs that report a gain to the government while delivering credit at rates that are below those charged for credit of similar risk in competitive markets. In those cases, the budget creates a bias in favor of federal credit programs compared with noncredit assistance and encourages expansion of federal credit services that can crowd out private provision of credit. Section 3.4 provides information on the likely size of the distortion for several federal credit programs.

6. The treatment of administrative costs, floating rate loans, and reestimates is also problematic (CBO 2006b), but those issues are beyond the scope of this chapter. 


\section{Insurance}

Insurance programs generally are budgeted for on a cash basis. For property casualty coverage such as federal flood or crop insurance, this approach is consistent with the annual coverage period that is standard in private contracts. For such insurance programs, market risk is unlikely to represent a major cost. Programs such as deposit and pension insurance, however, also can be viewed as credit guarantees, although they are not covered by the FCRA. Deposit and pension insurance are distinguished from the types of transactions covered by the FCRA by their lack of a fixed maturity date. The market risk associated with these programs is not treated as a budget cost.

\section{Investments in Private Securities}

Despite their similarity to federal loans, federal investments in private securities (e.g., stocks, corporate bonds, mortgages, foreign securities) are not covered by the FCRA. Rather, such investments are generally accounted for under the Office of Management and Budget (OMB) Circular A-11, which directs agencies to account for investments in private equities on a cash basis. That is, such investments are reported as outlays when made, despite the offsetting receipt of a security of equal value.

As for direct lending before the FCRA, scoring financial investments as outlays tends to discourage such activity, and until recently, federal investments in private securities have been quite limited. The possibility of booking a profit, however, has influenced several proposals to increase federal investments in private securities, usually in the context of Social Security reform. The passage of the 2001 amendments to the Railroad Retirement Act was a notable step in this direction.

The railroad retirement system, which predates Social Security, provides two tiers of benefits to retired railroad workers and their dependents. The first approximates benefits payable under Social Security. The second is specified in the Railroad Retirement Act and is based on years of railroad employment. Both tiers are financed by payroll taxes levied on employees and the railroads. The 2001 amendments authorized a newly created $\mathrm{Na}-$ tional Railroad Retirement Investment Trust (NRRIT) to invest in a diversified portfolio of risky securities. Further, the legislation specified that the purchase and sale of private securities by the Trust be treated in the budget as having no effect on budget outlays or the deficit. Only capital gains and losses were to be treated as affecting outlays.

The Railroad Retirement Act posed new challenges to the $\mathrm{CBO}$ and the OMB. There was general agreement that booking the market risk premium as expected profit, an offset to program expenses, should be avoided. Otherwise, the appearance of an arbitrage opportunity from selling Treasury 
securities and buying risky securities would reward increased risk-taking and perhaps encourage increased spending from illusory resources. Consistent with the legislation, it was agreed that the outlay of cash for securities would be treated as an equal value exchange. Gains and losses would be recognized in budget net outlays (gains as negatives) only as incurred. Notably, Treasury rates of return were adopted for projecting budget baseline income for the railroad retirement system. This effectively adjusts those returns for risk and avoids the appearance of a free lunch in budget projections. ${ }^{7}$

\subsubsection{Risk as a Budgetary Cost}

The federal budget serves multiple purposes: it is a record of and a partial check on total federal spending, and it allows trade-offs to be made among competing uses of resources. For the Congress, the budget resolution limits the budget costs that authorizing and appropriations committees can incur during a fiscal year. Those constraints create an incentive for the committees to choose policies that provide the greatest benefit from the limited budget resources available. To make comparisons between policy alternatives meaningful and to avoid accounting arbitrage opportunities, it is important that cost be recorded on a consistent basis.

The principle of consistency suggests the use of market prices in budgeting for federal financial commitments. The reason is that almost all noncredit transactions - including grants, purchases of goods, and the direct provision of services - appear in the budget at market prices. The largest category of expenditures is transfers. People get money, from Social Security benefits, food stamps, and so on. Cash is accounted for at its market price by definition - the real value of a dollar is what you can get by spending it on a consumption bundle. Then, there are government purchases from the private sector: military hardware, the labor of the federal workforce, buildings, computers, electricity, and so forth-all expenditures that occur at market prices, since goods, services, and capital are mostly purchased from private suppliers.

There are other categories of transactions where administrative prices appear to play a role, but ultimately, expenditures reflect market values. For instance, administrative prices set limits on Medicare payments, but no doctor is conscripted to participate in the program, and many choose not to when they can make more money elsewhere. Presumably, the economic value delivered to Medicare patients is in some ways tailored to make the administrative payment fair to the service provider, and it therefore is fundamentally still a market price (albeit a possibly distorted one).

It is useful to revisit the implications of incomplete markets for federal

7. This budget treatment did not prevent Congress from committing to spend these illusory gains. In assessing the sustainability of promised benefits, the legislation treated the equity premium as creating real resources. Under the act, benefits can be increased with higher-thanexpected investment returns, but beneficiaries are partially protected from investment losses. 
budgeting and to consider whether in a second-best world, risk adjustment is likely to move decisions closer to or further away from the social optimum. Although it is impossible to answer this definitively, we believe that the evidence on how budget numbers are used in practice strongly supports the contention that risk adjustment would improve allocative efficiency and transparency.

The conclusion that risk adjustment would be beneficial depends in part on the observation that the budget process affects resource allocation primarily by allowing policymakers to weigh the costs of alternative means of satisfying fairly specific goals - such as increasing access to higher education or encouraging investment in alternative energy sources. For these types of decisions, it is easy to find examples (several are described next) where risk adjustment reduces distortions in cost comparisons. It is much more difficult to imagine cases where risk adjustment would distort such comparisons. Broader trade-offs, where the question of the social discount rate is more important - such as whether to raise taxes or leave more debt to future generations - are decided primarily through the political process, not the budget process.

Several examples from legislation recently before Congress illustrate the problems that arise when market risk is not priced in the budget (see also in section 3.4). In the debate over reauthorization of the Higher Education Act, one point of contention was over whether to increase aid to low-income students by increasing Pell grants or by lowering the interest rate on subsidized loans. ${ }^{8}$ Since there is no risk charge on the loans, increasing their supply involves a lower budget cost than increasing outright grants of equal market value. Cost considerations favor loans over more-targeted Pell grants, even though the latter are generally thought to be the more efficient policy. ${ }^{9}$

A second example, which illustrates how ignoring risk adjustment can circumvent budget discipline and reduce transparency, is a provision (Title XVII) in the Energy Policy Act of 2005. That provision provides qualifying developers of innovative fuel technologies with federal loan guarantees. The legislation is structured so that the guarantees have zero budget cost, regardless of the size of the guarantee program. The zero budget cost is achieved by requiring the developers, most of which are subsidiaries of large utilities with ample access to capital markets, to pay an up-front fee that covers the estimated government cost of the credit guarantee. The value of the subsidy is the difference between the market value of the credit guarantee and value calculated without risk adjustment. In fact, even though no budget cost would be recorded, budget analysts use market value estimates to determine whether the subsidies are sufficient to make the projects viable. Growing

8. S. 1642 and H.R. 2669 (passed in July 2007).

9. Research suggests that grants are more effective than loans in inducing low-income students to pursue a college education. Further, there is growing concern that high levels of student loan debt create financial risk for students and for the government. 
awareness of this legislative mechanism has resulted in increasing numbers of proposals designed to exploit it.

Another concern arising from considerations of the second best is that the very limited use of discounting in the budget may favor using low discount rates when discounting does occur. Recall that the budget records most expenditures on a cash basis, with undiscounted numbers projected over a ten-year window, but that credit is on an accrual basis. The conjecture is that by discounting the cash flows associated with credit transactions but not discounting alternative expenditures, comparisons are distorted. While there is no doubt that cash-basis accounting can impede meaningful comparisons across alternatives with different expenditure patterns and time horizons, the limited use of discounting for credit and some other longlived contractual obligations tends to mitigate, not worsen, distortions due to timing differences. ${ }^{10}$ Returning to the example of higher education, consider the choice between instituting a grant program or new student loan program, both of which will run for ten years. The grant program authorizes $\$ 100$ million each year for new grants. In terms of resources committed to students in a given year, the equivalent student loan program would authorize lending each year in an amount such that the incremental annual subsidy is $\$ 100$ million. The comparable cost for each year is exactly what is recorded when credit is accounted for correctly on a net present value basis. ${ }^{11}$

In considering alternative approaches to incorporating market prices into budgeting for credit, an important conceptual question is how broadly to define cost. A broad view of opportunity cost suggests using a comprehensive measure of private production costs, including not only the market risk premium but also taxes, liquidity, marketing expenses, and so forth. That is, the cost is what it would cost to contract for the same service in the private market. ${ }^{12}$ The alternative is to focus on government production costs, including a risk charge. Private-sector costs can exceed government production costs because of the liquidity advantage of the Treasury market, ${ }^{13}$ the exemption of Treasury debt from state and local taxes, and the fact that the

10. Federal agencies address this limitation in part by undertaking capital budgeting exercises outside of the budget process to evaluate program alternatives.

11. One might still object to the mixing of accruals with cash and prefer that the budget serve entirely as a statement of cash flows.

12. The Monetary Control Act governing the charge the Fed assesses on priced services to depository institutions is a precedent for using a broad definition of opportunity cost in evaluating the cost of government services. The act mandates the Fed "to recover, over the long run, all direct and indirect costs actually incurred as well as imputed costs that would have been incurred, including financing costs, taxes, and certain other expenses, and the return on equity (profit) that would have been earned, if a private business firm provided the services" (Federal Reserve System, Docket No. OP-1229).

13. To the extent that the greater liquidity of the Treasury market is due to taxpayers bearing a firmer obligation to repay than available through private contracts, the savings to the government comes at a cost to taxpayers. 
government often avoids the higher marketing and service costs typically incurred by private providers. ${ }^{14}$

The question of whether to use private-sector or government production costs in estimating market values is not resolved by the principle of consistency - the budget generally records narrowly measured production costs for services the government produces, but it also records the full price of privately produced goods and services it purchases. In practice, it is difficult to separate out the various components of the market price of financial transactions. Hence, estimates based on comparable market prices are likely to reflect a fairly broad measure of opportunity cost, even when adjustments are made for identifiable differences, such as in administrative cost.

\subsubsection{Alternative Valuation Methods}

Three basic approaches can be used to incorporate market risk in the pricing of federal financial transactions: comparable market prices, riskadjusted discount rates, and options or derivative pricing. Although all methods should provide similar answers if correctly implemented, ${ }^{15}$ the most logical approach will vary with the transaction under consideration.

\section{Comparable Market Prices}

The most straightforward estimate of market cost is obtained in those instances when comparable products are offered by competitive private financial institutions. Clearly, government purchases of publicly traded stocks, bonds, and other financial securities fall into this category. Several federal credit offerings also have direct market counterparts, although favorable government terms can crowd out private provision. Federal Housing Administration (FHA) and Veterans Affairs (VA) mortgages, for instance, are similar in terms of size and borrower credit risk to some segments of the private market, where prices are readily observable. Still, adjustments must be made to account for differences in borrower and product characteristics.

\section{Risk-Adjusted Spreads}

For direct loan programs and sometimes for loan guarantees, risk adjusting the discount rate is often the most straightforward approach to estimating

14. The higher private-sector administrative costs generally reflect higher service levels and hence a different product than would be offered by the government. Adjusting for such differences is consistent with reporting program costs, not benefits.

15. It is well established in financial theory that for options such as loan guarantees, there is generally no single discount rate that can be applied to projected cash flows to obtain a correct answer. This complication is avoided using an options pricing approach, which implicitly incorporates the appropriate, potentially time-varying discount rate. Standard options pricing methods often produce cost estimates that are lower than those based on risk-adjusted rates. Nevertheless, all of the approaches yield estimates closer to market value than the current practice of omitting all risk adjustment. 
market value. Risk-adjusted discount rates are higher than comparable maturity Treasury rates, because they include a premium or spread that compensates investors for risk bearing and other costs of extending credit. An advantage of this method is that for direct loans, it allows budget analysts to follow procedures similar to those currently used under the FCRA, where projected future cash flows are discounted to present values using rates on Treasury securities of the same maturity. The method of risk-adjusted discount rates also involves projecting future cash flows and discounting them to the present at a maturity-matched rate, but the rate is risk adjusted.

The risk-adjusted spread often can be inferred from comparable market rates. For loans to rated corporations, loan maturity and credit rating provide guidance in identifying the expected return. For unrated companies, such as the small businesses served by the Small Business Administration (SBA), bank rates on small business loans serve as useful starting points. Estimated spreads can be further refined by taking into account attributes such as whether the loan is collateralized and other debt obligations of the borrower. For consumer credit such as student loans and mortgage insurance, the private market provides useful reference rates that can be further refined with information such as credit scores or collateral value. Even for loans that do not have a close market analog, it is possible to glean information from market rates. For instance, a loan to a young company developing new energy technologies could be valued with reference to spreads on highyield bonds or yields on venture capital investments in energy.

A number of caveats apply to the estimation and application of riskadjusted rates. Rarely can market spreads be applied directly, and the required adjustments can be subtle. First, consistency must be maintained between cash flows and discount rates. The approach under the FCRA of estimating expected cash flows already adjusts for expected losses in the numerator of present value calculations. To avoid double counting by using too high a discount rate, expected losses must be subtracted from the reference market spread. For example, if the reference spread were based on BB bond yields, the spread could be adjusted by subtracting average realized loss rates on $\mathrm{BB}$ bonds of similar maturity.

Identifying the cost of risk from primary market spreads - those based on loan terms at origination - generally requires further adjustments for administrative costs included in the rate spread. Secondary market prices, when available, largely avoid this complication. However, secondary market prices may be affected by subordination structures and other mechanisms to redistribute risk that also must be recognized and adjusted for.

Finally, adjustments must be made for the value of prepayment options embedded in many federal loans and guarantees and for prepayment options affecting market spreads.

Once market spreads are adjusted down for expected losses, administrative costs, and prepayment options, the remaining spread represents com- 
pensation not only for market risk but also for liquidity and tax differentials. From a broad opportunity cost perspective, liquidity and tax differentials can also be considered legitimate elements of government expense. Under a narrower interpretation of cost, the size of tax and liquidity effects must be estimated and subtracted to isolate the cost of market risk.

Additional care is required in using risk-adjusted spreads to value loan guarantees. On a direct loan, the spread over Treasury rates results in a lower present value of loan payments: the loan is worth less because of market risk. For a loan guarantee, risk adjusting discount rates increases guarantee value, because the guarantor assumes the market risk. That is, calculating the present value of guarantee payments effectively requires using a discount rate that is lower than the risk-free rate. This follows logically from the identity that the value of a loan with credit risk plus the value of a 100 percent credit guarantee equals the value of a risk-free loan. The risky loan is worth less than if cash flows were discounted at a risk-free rate, and the guarantee is worth more. This relation suggests that loan guarantees can be valued by taking the difference between the value of a risk-free loan with equivalent cash flows and the estimated market value of the underlying risky loan. However, complications arise in applying this approach for guarantees that cover less than 100 percent of loan value, as is often the case. The value of a guarantee can interact with other loan features such as the prepayment option, also complicating the analysis. For some loan guarantees, a conceptually and operationally more appealing approach is to rely on derivative pricing methods.

\section{Derivative Pricing}

A loan guarantee is equivalent to a put option, a derivative security that can be valued using well-established methods employed by private financial institutions. The equivalence arises because the lender has the option to put the loan to the guarantor - the writer of the put option - at a strike price equal to the face value of the loan. In the event of default, it is optimal for the lender to exercise the option, leaving the guarantor with a loss equal to the difference between the loan's face value and the amount collected in default.

Derivative pricing methods are often the preferred method for valuing loan guarantees to commercial enterprises. They are also relatively straightforward to apply in valuing insurance products that entail significant market risk, such as pension and deposit insurance. The method is rarely applied to credit extended to individuals, however, because critical model inputs, such as the underlying asset value or the conditions triggering default, are difficult to identify. In such cases, risk-adjusted rates are likely to be a more reliable starting point for estimation. The choice of valuation methods used in the examples described in section 3.4 are consistent with these considerations. 


\subsubsection{Additional Considerations}

The costs of modifying budget practice — including drafting and passing new legislation, retraining analysts, and revamping methods and modelsare a serious obstacle to the adoption of risk-adjusted pricing for federal budgeting. The added complexity could also make it harder to explain budget estimates to nonspecialists. An approach that would partially mitigate some of these problems would be to concentrate analytical efforts on developing standard models and relatively simple guidelines for valuation at the $\mathrm{CBO}$ and OMB. The results could then be disseminated to the relevant credit agencies, as was done by the OMB following the passage of the FCRA. The task of developing standard tools is made more feasible by the fact that only a few programs provide most of the assisted credit (see table 3.1).

\subsection{Evidence}

Whether it is worthwhile to incur the costs of budget reform depends on how serious the distortions are from ignoring the price of risk. A series of recent studies quantifies those effects in a variety of contexts. They also illustrate the potential and challenges of estimating the cost of risk for federal financial transactions.

\subsubsection{Loans and Loan Guarantees}

Strikingly, some of the government's largest credit programs - including mortgage insurance, small business 7(a) loan guarantees, rural utilities loans, and some student loan programs - appear to cost nothing or to make money for the government (see table 3.2). Extending the budget measure of subsidy cost to include the market cost of risk and other excluded factors seems likely to raise estimated subsidy costs and eliminate most zero and negative subsidies. This is because opportunities to extend credit on terms that more than cover cost tend to be taken by private lenders without taxpayer assistance. A growing body of evidence is consistent with this expectation.

\section{Corporate Debt Guarantees}

The CBO (2004a) uses a derivatives pricing approach to valuing loan guarantees and compares the results with and without the inclusion of a market risk premium. The study looks at two similarly structured loan guarantees to distressed corporations: $\$ 1.5$ billion to Chrysler in 1980 , and $\$ 380$ million to America West Airlines (AWA) in 2002. In exchange, the government received guarantee fees and ten-year warrants granting the right to purchase shares at a fixed strike price.

For both Chrysler and AWA ex ante, the net cost to the government is the cost of the guarantee less the value of warrants and guarantee fees. Uncertainty about default, prepayment, and future asset and stock values affects 
Table 3.1

New federal direct loans and guarantees by program, 2005 (billions of dollars and percent of total)

$\begin{array}{lrc}\text { Direct Loans } & & \\ \quad \text { Stafford and PLUS student loans } & \\ \text { Rural electric and telecommunications } & \$ 12.9 & 52.4 \% \\ \text { Rural community facilities } & 4.8 & 19.5 \\ \text { Rural Housing Insurance Fund } & 1.7 & 6.9 \\ \text { SBA disaster loans } & 1.3 & 5.3 \\ \text { Other } & 1.3 & 5.3 \\ \text { Total direct loans } & 2.6 & 10.6 \\ \text { Guaranteed loans } & \$ 24.6 & \\ \text { Stafford and PLUS student loans } & \\ \text { FHA Mutual Mortgage Insurance } & & \\ \text { FHA general and special risk } & \$ 43.3 & 22.6 \\ \text { VA housing } & 58.0 & 30.3 \\ \text { SBA general business } & 19.7 & 10.3 \\ \text { Other } & 22.5 & 11.8 \\ \text { Total guaranteed loans } & 19.9 & 10.4 \\ \end{array}$

Source: OMB, Analytical Perspectives, FY 2007, pp. 89-90.

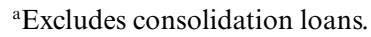

Table 3.2

Selected loan and loan guarantee subsidy rates

\begin{tabular}{lc}
\hline & Subsidy rate (\%) \\
\hline Direct loans obligations & \\
Rural Housing Insurance Fund & 14.70 \\
SBA disaster loans & 12.86 \\
Agricultural Credit Insurance Fund & 7.38 \\
Rural community advancement & 6.81 \\
Student loans & 3.32 \\
Rural electric and telecommunications & -0.96 \\
Guaranteed loan commitments & 11.09 \\
Student loans & 5.07 \\
Commodity Credit Corporation export & 1.09 \\
Export-Import Bank & 3.27 \\
Agricultural Credit Insurance Fund & 0.0 \\
SBA 7(a) & -1.80 \\
FHA, MMI & -0.85 \\
FHA, general and special risk & -0.32 \\
VA housing &
\end{tabular}

Source: OMB, Analytical Perspectives, FY 2007, pp. 89-90.

each cost component. Following a standard binomial modeling approach (see CBO [2004b] for technical details), the stochastic evolution of asset value is modeled based on expected returns and historical volatility of assets, estimated from historical stock return and industry data. Default is triggered when asset value falls below the value of maturing debt and current liabilities. 
Similarly, prepayment is triggered when assets exceed liabilities, since recovery would likely allow a switch to lower-fee, nongovernment financing. The distribution of cash flows to the government fans out over time, with large gains in states of the world where the firm recovers and the warrants become valuable and with large losses in states where the firm defaults and the warrants are worthless. ${ }^{16}$

The same statistical models for estimating the distribution of future cash flows are used for both the FCRA-style and market value estimates, ensuring that the underlying cash flows are the same for both. Only the discount rates differ. The FCRA estimates are discounted using a contemporaneous Treasury rate, whereas the market value estimates incorporate the price of risk implicitly through the binomial options pricing approach.

The inclusion of the price of market risk has a large effect on the value of guarantees to high-risk borrowers. For AWA, the price of risk changes the net value from a gain to the government of 9.8 percent of loan value to a loss of 11.5 percent. For Chrysler, the net loss increases from 7.2 percent to 15.9 percent of the amount loaned. Table 3.3 shows the results for each firm, broken down into guarantee, fee, and warrant components. Risk adjustment increases the value of loan guarantees, because defaults tend to occur in bad aggregate states. Conversely, it decreases the value of warrants, which tend to be most valuable in good aggregate states. Two offsetting effects on fee value make the net effect of risk adjustment small: prepayments reduce fees in good times, but defaults reduce fees in bad times.

\section{FHA Mortgage Guarantees}

The FHA operates the Mutual Mortgage Insurance program (MMI), which provides access to homeownership to individuals who lack the savings, credit history, or income to qualify for a conventional mortgage. Under this program, the FHA provides credit guarantees on fifteen- and thirty-year fixed and adjustable rate, amortizing mortgages. The FHA charges borrowers both an up-front and annual fee for this service. To target the program to low- and moderate-income borrowers, the FHA sets limits on the dollar value insured.

Conveniently for valuation, the MMI program has a close counterpart in the private sector, and market prices are readily available. In fact, the FHA share of the mortgage guarantee business has declined sharply in the mid2000 s, as private competitors attracted an increasing portion of relatively low-risk borrowers by selectively pricing below the FHA.

In a recent analysis of proposed changes in the MMI program, the $\mathrm{CBO}$ (2006a) includes a calculation of the effect of market risk on program cost. Although comparable market prices are available, adjustments had to be made for differences in loan-to-value ratios, the government's lower market- 
Comparing subsidy rates, credit reform versus market values (percentages)

\begin{tabular}{llllll}
\hline & \multicolumn{2}{c}{ AWA } & & \multicolumn{2}{c}{ Chrysler } \\
\cline { 2 - 3 } \cline { 6 - 6 } \cline { 6 - 7 } & Credit reform & Market value & & Credit reform & Market value \\
\hline Warrants & $(21.2)$ & $(13.2)$ & & $(7.9)$ & $(5.4)$ \\
Guarantee fees paid & $(13.8)$ & $(14.9)$ & & $(1.93)$ & $(1.86)$ \\
Loan guarantee & 25.2 & 39.6 & & 17.0 & 23.2 \\
Net government subsidy & $(9.8)$ & 11.5 & & 7.2 & 15.9 \\
\hline
\end{tabular}

ing costs, and differences in the distribution of credit scores for FHA-insured versus privately insured borrowers.

The effect of market risk on estimated subsidy cost is once again considerable. After adjusting for the loan differences the CBO estimates that the FHA's subsidy cost for the MMI program is 56 basis points per year versus a 33 basis point cost without risk adjustment. With new annual guarantee volume of about $\$ 40$ billion, the 23 basis point difference indicates a cost of risk of $\$ 90$ million per cohort.

\section{Student Loans}

Two of the largest federal credit programs are the Federal Family Education Loan (FFEL) program and the Federal Direct Student Loan (FDSL) program. The FFEL guaranteed loans are originated and serviced by private lenders but are guaranteed against credit risk by the Federal Government. Private lenders are also assured of a gross return that is a spread over the commercial paper rate through payments from the Federal Government that make up the difference between the student loan rate and the guaranteed rate. The direct loan program provides funds directly from the Federal Government to students, without the use of a private financial intermediary. The terms on guaranteed and direct loans are approximately the same for students and are generally more favorable than those available to consumers on nonfederal unsecured loans.

As is the case with federal mortgage insurance, a private market has developed in parallel with the federal student loan program, mostly to provide funds to students who have reached the federal borrowing limit. Using a combination of data from private and federal lenders, Lucas and Moore (see chapter 7 in this volume) have estimated that market risk adds 1 to 2 percentage points per year to the rate charged on private student loans. Using this estimate to calculate the cost of federal student loans adds about 8 percentage points to the subsidy rate for both guaranteed and direct loans.

\section{SBA 7 (a) Loans}

To promote access to loan capital for small businesses, the SBA offers loan guarantees covering 50 percent to 85 percent of principal. In fiscal year 
2005 , new guarantees issued by the agency totaled about $\$ 14$ billion. The interest rate paid by borrowers on those loans is negotiated with the lender and appears to be about 5 percent over short-term Treasury rates (a premium that is hard to reconcile with historically low default rates and the substantial credit guarantee). Borrowers also pay guarantee fees to the SBA.

By applying an options pricing model to the SBA's cash flow data, the $\mathrm{CBO}$ has estimated that taking account of market risk and recent default experience doubles the cost of 7(a) guarantees from 1.1 percent of the loan amount to 2.2 percent $(\mathrm{CBO}, 2007)$.

\subsubsection{Insurance Programs}

Unlike federal credit, insurance is budgeted for on a cash rather than accrual basis. Nevertheless, multiyear analyses suggest that the cost of risk is significant for some of these programs.

\section{Pension Benefit Guaranty Corporation (PBGC) Insurance}

The cost of federal insurance for defined benefit pension plans provided by the PBGC has two main drivers: it increases with the frequency of insolvency of plan sponsors and with the shortfall between plan assets and plan liabilities. Both of these factors contribute to higher payouts by the PBGC in bad aggregate states: insolvency rates increase in downturns, and the value of plan assets, which are heavily invested in equities, falls relative to the more stable value of plan liabilities. Consequently, the cost of market risk is a large component of the market price of this insurance.

The CBO (2005) evaluates the market value cost of insurance using an options pricing framework and compares it to an estimate based on identical cash flows but risk-free discounting. ${ }^{17}$ The market value of federal pension insurance net of premiums for single-employer plans over the next ten years is estimated to be $\$ 86.7$ billion. That sum includes $\$ 23.3$ billion for plans that have already been terminated and $\$ 63.4$ billion for insured claims projected to be put to the PBGC during the period. For the forward-looking component of cost, discounting new projected PBGC claims at Treasury rates implies a present value cost estimate of $\$ 32.4$ billion, or just over half the market value of $\$ 63.4$ when the cost of market risk is included.

\section{Deposit Insurance}

Recent estimates of the cost of federal deposit insurance also indicate a significant contribution from market risk. For example, Falkenheim and Pennacchi (2003) and Pennacchi (2006) develop an options pricing model

17. The compound nature of the option is accommodated using a risk-neutral Monte Carlo simulation approach. The model is used to evaluate the joint probability distribution of insolvency and the shortfall in plan assets for each covered firm. The total discounted cost is then a sum over all covered firms for which data is available. Pennacchi and Lewis (1999) examine a related pricing model. 
for deposit insurance to banks and thrifts. To differentiate the market cost of deposit insurance from the expected cost discounted at risk-free rates, they report and compare the risk-adjusted or "risk-neutral" cumulative ten-year probabilities of bank insolvency with the cumulative actual or "physical" probabilities of insolvency. Their results show markedly higher cumulative risk-neutral probabilities of default than actual probabilities. For example, the average cumulative ten-year probability of insolvency for a large sample of private banks was 11.19 percent (risk neutral) and 4.5 percent (actual). For the publicly traded sample, the respective probabilities were 12.13 percent (risk neutral) and 4.98 percent (actual). ${ }^{18}$

\subsubsection{Investments in Private Securities}

If investments in private securities were treated analogously to credit under the FCRA, an apparent arbitrage opportunity would arise (CBO, 2003). ${ }^{19}$ Imagine issuing $\$ 100$ billion in Treasury bonds yielding 5 percent and investing the money in private equities. Clearly, in market value terms, this is a neutral transaction for the government - equal value is paid and received. When the cash flows from the equity investment are projected into the future, those cash flows include an equity premium, conservatively, 4 percent more than the risk-free rate. At the end of ten years, the accumulated value of the equity is then expected to be $\$ 100(1.09)^{10}=\$ 237$ billion. Discounting at the Treasury rate of 5 percent, the present value of the equity investment is $\$ 145$ billion. Under FCRA-type accounting, the transaction appears to make $\$ 45$ billion for the government (the $\$ 145$ equity value less the $\$ 100$ in Treasury securities issued).

Failing to take into account market risk can also distort the perception of the magnitude of liabilities, as discussed in Geanakoplos and Zeldes (see chapter 8 in this volume) in the context of Social Security. Further, an even larger discrepancy between market value and estimated cost can arise for benefit guarantees, such as those contemplated in some proposals to supplement Social Security with investments in private securities (Lachance and Mitchell 2002; CBO 2006b; Biggs, Burdick, and Smetters 2009). Such guarantees provide a floor on benefits to protect against poor investment returns. Like credit guarantees, benefit guarantees are a type of put option that confers the right to sell an asset for a predetermined price should it lose value. Benefit guarantees are particularly susceptible to market risk, however, because of the leveraged exposure to stock market risk.

Many observers inside and outside the government have emphasized the importance of avoiding the temptation to treat the risk premium as an

18. The difference between actual and risk-neutral probabilities over this horizon does not map directly into a cost differential, because it neglects time value, but nevertheless, it is indicative of the relative magnitude of costs with and without risk adjustment.

19. At present, private investments are accounted for as cash outlays in the budget under the OMB Circular A-11. 
arbitrage opportunity in the budget. For instance, in describing the budget treatment of the private investments in the railroad retirement fund discussed previously, the OMB writes, ${ }^{20}$

Equities and private bonds earn a higher return on average than the Treasury rate, but that return is subject to greater uncertainty. Sound budgeting principles require that estimates of future [railroad retirement] trust fund balances reflect both the average return and the cost of risk associated with the uncertainty of that return. ... [T] he difference between the expected return of a risky liquid asset and the Treasury rate is equal to the cost of the asset's additional risk as priced by the market. Following through on this insight, the best way to project the rate of return on the Fund's balances is to use a Treasury rate. This will mean that assets with equal economic value as measured by market prices will be treated equivalently, avoiding the appearance that the budget could benefit if the government bought private sector assets.

The 1999 Social Security Technical Advisory Panel ${ }^{21}$ similarly warns against presentations "that tend to show that 'financial arbitrage'-borrowing to purchase equities with a higher expected rate of return - creates some sort of free lunch" (p. 7). Nevertheless, agreement has yet to be reached on how the risk premium should be treated in the budget or in other types of government financial reports.

Opposition to booking an arbitrage profit from government risk-taking should not be interpreted as an argument against incorporating private investments into the Social Security system. As suggested by Diamond and Geanakoplos (1999), there may be legitimate reasons to reallocate risk via the retirement system - for instance, if some people are constrained from participating privately in financial markets by borrowing constraints. These considerations are important for evaluating the relative merits of alternative policy proposals. Here, however, the emphasis is on accounting for cost, which, for the reasons discussed earlier, seems best accomplished using market prices.

\section{References}

Arrow, K., and G. Debreu. 1954. Existence of an equilibrium for a competitive economy. Econometrica 22 (3): 265-90.

Arrow, K., and R. Lind. 1970. Uncertainty and the evaluation of public investment decisions. American Economic Review 60 (3): 364-78.

20. "The Budget System and Concepts," chapter 26, Analytical Perspectives, FY 2007. Budget of the US Government, p. 392. Available at: http://www.budget.gov/budget.

21. 1999 Technical Panel on Assumptions and Methods, Report to the Social Security Advisory Board. Available at: http://www.ssab.gov/publications/financing/tech99.pdf. 
Bazelon, C., and K. Smetters. 1999. Discounting inside the Washington, D.C. Beltway. Journal of Economic Perspectives 13 (4): 213-28.

Biggs, A., C. A. Burdick, and K. Smetters. 2009. Pricing personal account benefit guarantees: A simplified approach. In Social security policy in a changing environment, ed. J. R. Brown, J. B. Liebman, and D. A. Wise, 229-55. Chicago: University of Chicago Press.

Bohn, H. 2004. Intergenerational risk sharing and fiscal policy. Meeting Paper no. 22. University of Connecticut, Society for Economic Dynamics.

Congressional Budget Office (CBO). 2003. Evaluating and accounting for federal investment in corporate stocks and other private securities. Washington, DC: CBO.

-2004a. Estimating the value of subsidies for federal loans and loan guarantees. Washington, DC: CBO.

. 2004b. Technical notes on valuing federal loans and loan guarantees using options pricing methods. Washington, DC: CBO.

. 2005. The risk exposure of the Pension Benefit Guaranty Corporation. Washington, DC: CBO.

2006a. Assessing the government's costs for mortgage insurance provided by the Federal Housing Administration. Attachment to letter to Congressman Jeb Hensarling. Available at: http://www.cbo.gov/doc.cfm?index $=7412 \& z z z=33862$. 2006b. Evaluating benefit guarantees in social security. Washington, DC: CBO. 2007. Federal financial guarantees under the Small Business Administration's 7(a) program. Washington, DC: CBO.

Debreu, G. 1959. Theory of value: An axiomatic analysis of economic equilibrium. New Haven: Yale University Press.

Diamond, P. 1967. The role of the stock market in a general equilibrium model with technological uncertainty. American Economic Review 57 (3): 759-76.

Diamond, P., and J. Geanakoplos. 1999. Social security investment in equities I: Linear case. NBER Working Paper no. 7103. Cambridge, MA: National Bureau of Economic Research, April.

Falkenheim, M., and G. Pennacchi. 2003. The cost of deposit insurance for privately held banks: A market comparable approach. Journal of Financial Services Research 24 (2-3): 121-48.

Fama, E. F., and K. R. French. 1992. The cross-section of expected stock returns. Journal of Finance 47 (2): 427-65.

Gale, W. 1991. Economic effects of federal credit programs. American Economic Review 81 (1): 133-52.

Heaton, J., and D. Lucas. 1996. Evaluating the effects of incomplete markets on risk sharing and asset pricing. Journal of Political Economy 104 (3): 443-88.

Hirshliefer, J. 1964. Efficient allocation of capital in an uncertain world. American Economic Review 54:72-85.

1966. Investment decisions under uncertainty: Applications of the state preference approach. Quarterly Journal of Economics 80:252-77.

Jorgenson, D. W., W. Vickrey, T. C. Koopmans, and P. A. Samuelson. 1964. Discussion. American Economic Review 54:93-96.

Kaplow, L. 2006. Discounting dollars, discounting lives: Intergenerational distributive justice and efficiency. NBER Working Paper no. 12239. Cambridge, MA: National Bureau of Economic Research, May.

Lachance, E. M., and O. Mitchell. 2002. Understanding individual account guarantees. NBER Working Paper no. 9195. Cambridge, MA: National Bureau of Economic Research, September.

Lintner, J. 1965. The valuation of risk assets and the selection of risky investments in stock portfolios and capital budgets. Review of Economics and Statistics 47 (1): $13-37$. 
Lucas, D., and M. Phaup. 2008. Reforming credit reform. Public Budgeting and Finance 28 (4): 90-110.

Modigliani, F., and M. H. Miller. 1958. The cost of capital, corporation finance, and the theory of investment. American Economic Review 48 (3): 261-97.

Pennacchi, G. 2006. Deposit insurance, bank regulation, and financial system risks. Journal of Monetary Economics 53 (1): 1-30.

Pennacchi, G., and C. Lewis. 1999. Valuing insurance for defined-benefit pension plans. In Advances in futures and options research, vol. 10, ed. P. Boyle, G. Pennacchi, and P. Ritchken, 135-69. Greenwich, CT: JAI Press.

Roll, R. 1977. A critique of the asset pricing theory's tests. Journal of Financial Economics 4:129-76.

Sandmo, A. 1972. Discount rates for public investment under uncertainty. International Economic Review 13 (2): 287-302.

Sandmo, A., and J. Dreze. 1971. Discount rates for public investment in closed and open economies. Economica 38 (152): 395-412.

Sharpe, W. F. 1964. Capital asset prices: A theory of market equilibrium under conditions of risk. Journal of Finance 19 (3): 425-42.

Stern, N. 2007. The Economics of Climate Change: The Stern Review. Cambridge, UK: Cambridge University Press.

Stiglitz, J., and A. Weiss. 1981. Credit rationing in markets with imperfect information. American Economic Review 71 (3): 393-410.

\section{Comment Henning Bohn}

Debbie Lucas and Marvin Phaup present an excellent overview of how economists and policymakers should think about risk-taking in the public sector. The first part reviews the economic theory of risk sharing and of how risks are priced. The second part applies the principles of state-contingent claims pricing to practical questions of budget accounting. I agree wholeheartedly with the two main points: taking a systematic risk has a cost to the government, and the market value of such risks should be reflected in the budget.

The theoretical part reviews state-contingent claims pricing - the standard technical framework for pricing risks in finance-in a way that should be readable in policy circles. The key insights are that taking systematic risks is costly and that options are valuable. Lucas and Phaup also discuss how finance theory can be adapted to deal with realistically incomplete markets. The main lessons are that public policy can improve risk sharing and that well-designed risk-sharing policies can improve social welfare.

The applied part applies state-contingent claims pricing to questions of budget accounting. The key points are that assets and liabilities should be valued at market, that cost-benefit calculations should be based on economic opportunity cost, that costs should be recognized when they are accrued and

Henning Bohn is professor of economics at the University of California, Santa Barbara. 